\title{
Physical therapy of a child with multiple sulfatase deficiency
}

\author{
IGOR GRYGUS ${ }^{1}$, OLHA NAHORNA ${ }^{2}$, STANISLAV TABACHNIKOV ${ }^{3}$, LIUDMYLA PRYMACHOK ${ }^{4}$, \\ OLEKSANDR CHERNIIENKO ${ }^{5}$ \\ ${ }^{1,2}$ Institute of Health, National University of Water and Environmental Engineering, Rivne, UKRAINE \\ ${ }^{3}$ National Academy of Higher Education Sciences of Ukraine, Kyiv, UKRAINE \\ ${ }^{4,5}$ Rivne Medical Academy of Rivne Regional Council, Rivne, UKRAINE
}

Published online: October 30, 2021

(Accepted for publication October 15, 2021)

DOI:10.7752/jpes.2021.s5388

\begin{abstract}
In the article the tasks and means of physical therapy of children with multiple sulfatase deficiency (MSD) were analysed. The purpose of the study presented in the article was an argumentation of applying the means of physical rehabilitation in an individual comprehensive program of physical therapy of children with MSD. Research methods: analysis of scientific and methodological sources of domestic and foreign authors, systematization of clinical manifestations of MSD in the age aspect from the point of view of physical therapist. The data of the literature sources on the research topic, analysis of the clinical phenotype of multiple sulfatase deficiency and potential complications of the disease were observed, applying of physical therapy's means was motivated. The clinical case of a patient with a late-infantile form of the disease was highlighted. The analysis of the symptom complex of multiple sulfatase deficiency and the use of physical therapy for a child with MDS was performed. This allowed to form the main vectors of patient supervision to prevent complications and improve quality of life. Used respiratory gymnastics, game therapy with a child according to the method of "hand in hand", therapeutic physical culture, massage, positioning of the child in a verticalizer, in a specialized chair, orthoses, passive mobilization of joints were used. It was revealed that in the result of physiotherapy impact, functioning of the gastrointestinal tract and psycho-emotional sphere got better, orthopaedic deformities were managed to avoid, qualitative change of blood tests were traced that was confirmed by laboratory. Serum iron, cyanocobalamin (vitamin B12), folic acid, and zinc were monitored. Anthropometric data, which indicate the physical development of the child, meet the age norms. The effectiveness of individual program of rehabilitation of a child with MSD, therefore, was shown. The decision of the treatment algorithm and the development of a personalized coordinated comprehensive program of physical therapy of children with MSD require thorough attention.

Key words: genetic orphan disease, massage, therapeutic physical culture, verticalization, positioning.
\end{abstract}

\section{Introduction.}

Genetic orphan diseases are characterized by a variety of symptoms and a complexity of differential diagnosis (Lallemant-Dudek, 2021; Phenotypic-genetic relations, 2020; Savliuk et al., 2020; Yevtushenko, 2016). Usually, the pathology is detected in the first years of a child's life and leads to disability and requires routine, systematic, lifelong supportive treatment (Mykhaylova et al., 2013, 2014; Nesterchuk et al., 2019; Novikov, 2014; Pichkur, 2017; Shestopal et al., 2021). However, in certain cases, it is quite difficult to classify a rare genetic disease by nosology, it is possible an absence of clinically unified treatment protocols. In such circumstances, a person needs a palliative care, the coordinated actions of doctors, physical therapists, social workers, family members (Rare diseases, 2020).

275 orphan diseases were approved in Ukraine (Committee on Healthy Nation, 2020). In the decree of the Ministry of Health of Ukraine from 27.10.2014 "About the approval of the list of rare (orphan) diseases" taking into account the changes and additions from December 24, 2019 N 2664 this pathology is not specified. In the document, only rare diseases that lead to reducing of patients' lifespan or lead to patients' disability are indicated and for those who already have certain methods of treating. There is no register of citizens with rare diseases in the country, as a result of that there are a number of problems. Taking into account this situation, the adoption of the National Strategy on Prevention, Diagnosis and Treatment of Rare (Orphan) Diseases was initiated in Ukraine (Rare diseases, 2020).

The special attention of specialists is required by an extremely rare disease requires - multiple sulfatase deficiency (MSD) that is a neurometabolic disorder inherited in autosomal recessive form (Phenotypic-genetic relations, 2020; Annunziata et al., 2007).

We have not found any information about this pathology in the domestic professional publications. Foreign reports contain limited data about this genetic disease. They mainly cover genetic diagnostic studies and systematize the clinical phenotype (Annunziata et al., 2007; Guerra et al., 1990; Horwitz, 1979; Jaszczuk et al., 
2017; Savostyanov, 2020). An absence of clinical protocols and guidelines regarding the treatment of children with MSD encourages to analyse the course of this rare disease as well as developing a physical therapy program.

\section{Materials and methods.}

The purpose of the study: argumentation of using the means of physical rehabilitation in the individual comprehensive physical therapy program for children with multiple sulfatase deficiency.

The methods of research: analysis of scientific and methodological sources of domestic and foreign authors, systematization of clinical manifestations of MSD in the age aspect from the point of view of physical therapist.

The result of the study: Multiple sulfatase deficiency (MKH-10 - E 75.2. from the group of lysosomal storage diseases, MeSH - D052517, MIM \# 272200) is a rare autosomal-recessive congenital metabolic disorder.

There are neonatal, late infantile and juvenile subtypes of the disease (Schlotawa et al., 2020; Multiple sulfatase deficiency, 2021).

The neonatal type of MSD is the most severe form with a post-natal onset and a wide range of clinical symptoms like mucopolysaccharidosis. According to several published cases, all neonatal patients with MSD died during the first year of life (Ahrens-Nicklas et al., 2018; Burch et al., 1986; Guerra et al., 1990).

The late infantile type of MSD resembles the late infantile metachromatic leukodystrophy with progressive loss of mental and motor abilities. These clinical features are combined with other symptoms of single sulfatase deficiency, such as dysmorphism, skeletal changes and ichthyosis (Ahrens-Nicklas et al., 2018; Guerra et al., 1990).

The late infantile type of MSD can be divided into severe and weakened form. The weakened form shows a reduced number of symptoms and later manifestations. The majority of the MSD cases are late infantile forms.

\section{Results.}

The clinical case. Boy, 3 years and 2 months. He has a late infantile type, severe form of MSD.

In the table 1, a comparative analysis of the clinical phenotype of MSD, as reported in publications (Ahrens-Nicklas et al., 2018; Schlotawa et al., 2020) and our patient's symptom complex is offered, as well as means of therapeutic intervention regarding the systems of the body involved in the pathological process (Grygus et al., 2019, 2021; Savliuk et al., 2020).

Comparative analysis of the clinical phenotype of multiple sulfatase deficiency and the use of physical therapy's means for children with MSD

\begin{tabular}{|c|c|c|c|}
\hline System & $\begin{array}{c}\text { Potential clinical } \\
\text { problems described in } \\
\text { the literature }\end{array}$ & $\begin{array}{c}\text { Clinical } \\
\text { problems of the } \\
\text { patient }\end{array}$ & $\begin{array}{l}\text { Means of therapeutic } \\
\text { intervention }\end{array}$ \\
\hline $\begin{array}{l}\text { Dermatological } \\
\text { problems }\end{array}$ & $\begin{array}{l}\text { Ichthyosis } \\
\text { Hyperpigmented } \\
\text { plaques }\end{array}$ & $\begin{array}{l}\text { Dry skin, plaques } \\
\text { according the } \\
\text { type of ichthyosis }\end{array}$ & $\begin{array}{l}\text { Massage (under the influence of } \\
\text { massage dead cells of the } \\
\text { epidermis are exfoliated and } \\
\text { removed) improves the excretory, } \\
\text { respiratory, thermoregulatory } \\
\text { functions of the skin (Vakulenko } \\
\text { et al., 2020). }\end{array}$ \\
\hline $\begin{array}{l}\text { Musculoskeletal } \\
\text { system }\end{array}$ & $\begin{array}{l}\text { Stenosis of the spine, } \\
\text { that leading to } \\
\text { compression. } \\
\text { The disorders of tone } \\
\text { (hypotension and / or } \\
\text { spasticity) }\end{array}$ & $\begin{array}{l}\text { Local spasticity } \\
\text { of the afferent } \\
\text { muscles and } \\
\text { ankle joint; } \\
\text { Deformation of } \\
\text { the thorax in the } \\
\text { form of } \\
\text { expansion of 10- } \\
12 \text { pairs of costal } \\
\text { arch }\end{array}$ & $\begin{array}{l}\text { Verticalizer, orthosis, massage, } \\
\text { passive joint mobilization, } \\
\text { positioning, therapeutic } \\
\text { gymnastics (Order of the Ministry } \\
\text { of Health of Ukraine N 286, 2013; } \\
\text { Korolkov et al., 2016; Dido et al., } \\
2021 \text { ). }\end{array}$ \\
\hline $\begin{array}{l}\text { Neurological } \\
\text { status }\end{array}$ & $\begin{array}{l}\text { Peripheral neuropathy } \\
\text { Cramps } \\
\text { Changes in vision, } \\
\text { headaches, vomiting }\end{array}$ & $\begin{array}{l}\text { Convulsive } \\
\text { readiness on EEG }\end{array}$ & $\begin{array}{l}\text { Head circumference measurements } \\
\text { in all clinical meetings. } \\
\text { Neuropsychological testing by a } \\
\text { neurologist, as indicated clinically }\end{array}$ \\
\hline
\end{tabular}




\begin{tabular}{|c|c|c|c|}
\hline $\begin{array}{l}\text { Cognitive and } \\
\text { motor regression }\end{array}$ & $\begin{array}{l}\text { Beginning and } \\
\text { the speed of regression } \\
\text { progress are individual } \\
\text { and depend on the age } \\
\text { of indicating the first } \\
\text { symptoms }\end{array}$ & $\begin{array}{l}\text { Malignant } \\
\text { progressive } \\
\text { regression } \\
\text { psychomotor } \\
\text { development }\end{array}$ & $\begin{array}{l}\text { Playing with a child according to } \\
\text { the method of "hand in hand" } \\
\text { (Unified clinical protocol of } \\
\text { primary, secondary (specialized) } \\
\text { and tertiary (highly specialized) } \\
\text { medical care and medical } \\
\text { rehabilitation "Cerebral palsy and } \\
\text { other organic brain lesions in } \\
\text { children with motor disorders", } \\
\text { 2019; Manual Ability } \\
\text { Classification System for children } \\
\text { with cerebral palsy } 4-18 \text { years, } \\
\text { 2010), exercise therapy, massage, } \\
\text { positioning of the child in the } \\
\text { verticalizer, in a specialized chair. }\end{array}$ \\
\hline $\begin{array}{l}\text { Nutrition and } \\
\text { gastroenterological } \\
\text { problems }\end{array}$ & $\begin{array}{l}\text { A poor gastrointestinal } \\
\text { motility (feeding } \\
\text { intolerance, } \\
\text { constipations) } \\
\text { Hepatosplenomegaly } \\
\text { Gallbladder problems }\end{array}$ & Constipations & $\begin{array}{l}\text { Massage C3-C4; T6-T10 from the } \\
\text { right side. } \\
\text { Following the rule of safety during } \\
\text { feeding-nutrition in a specialized } \\
\text { chair, as these problems can lead } \\
\text { to secondary respiratory } \\
\text { complications such as aspiration } \\
\text { pneumonia; occupational therapy } \\
\text { intervention }\end{array}$ \\
\hline $\begin{array}{l}\text { Gastrointestinal } \\
\text { and urinary } \\
\text { problems }\end{array}$ & $\begin{array}{l}\text { A difficult act of } \\
\text { defecation due to } \\
\text { insufficient motor } \\
\text { function of the intestine } \\
\text { A constipation and slow } \\
\text { motility of the } \\
\text { gastrointestinal tract }\end{array}$ & $\begin{array}{l}\text { A difficult act of } \\
\text { defecation due to } \\
\text { insufficient motor } \\
\text { function of the } \\
\text { intestine. } \\
\text { Constipation and } \\
\text { slow motility of } \\
\text { the } \\
\text { gastrointestinal } \\
\text { tract }\end{array}$ & $\begin{array}{l}\text { A massage: small intestine C3-C4; } \\
\text { T9-T2, ascending intestine T9-L1, } \\
\text { rectum T11-T12; L1-L2. } \\
\text { Verticalization. }\end{array}$ \\
\hline $\begin{array}{l}\text { Ophthalmic } \\
\text { problems }\end{array}$ & $\begin{array}{l}\text { Glaucoma } \\
\text { Corneal opacity } \\
\text { Retinopathy, including } \\
\text { retinitis pigmentosa } \\
\text { Strabismus } \\
\text { Optic nerve disorders } \\
\text { Cataract } \\
\end{array}$ & Not examined & $\begin{array}{l}\text { Verticalization for } \\
\text { maximum opportunity for face-to- } \\
\text { face communication. }\end{array}$ \\
\hline $\begin{array}{l}\text { Oral problems and } \\
\text { problems with the } \\
\text { jaw }\end{array}$ & $\begin{array}{l}\text { A hyperplastic gum } \\
\text { Dental complications, } \\
\text { including tooth enamel } \\
\text { ruining. }\end{array}$ & $\begin{array}{l}\text { Ruining of tooth } \\
\text { enamel. }\end{array}$ & $\begin{array}{l}\text { Consultation of professionals in } \\
\text { area of child stomatology. }\end{array}$ \\
\hline $\begin{array}{l}\text { Otolaryngological } \\
\text { problems }\end{array}$ & $\begin{array}{l}\text { Hearing impairment } \\
\text { Recurrent otitis } \\
\text { Obstruction of the } \\
\text { mouth, pharynx and } \\
\text { upper respiratory tract } \\
\text { with progressive } \\
\text { narrowing of the } \\
\text { airways }\end{array}$ & Not examined & $\begin{array}{l}\text { A use of sound toys. } \\
\text { The passive breathing exercises } \\
\text { with prolonged exhalation. }\end{array}$ \\
\hline $\begin{array}{l}\text { Problems of } \\
\text { respiratory system }\end{array}$ & $\begin{array}{l}\text { An obstructive } \\
\text { pulmonary disease, } \\
\text { Restrictive lung disease } \\
\text { Central apnea } \\
\text { Peripheral apnea } \\
\text { Sleep problems } \\
\text { Recurrent pneumonia }\end{array}$ & Not observed & $\begin{array}{l}\text { Breathing exercises for effective } \\
\text { lung ventilation and improving the } \\
\text { excursion of the chest, massage } \\
\text { C3-C4; T3-T9. } \\
\text { Passive breathing exercises with } \\
\text { prolonged exhalation. }\end{array}$ \\
\hline
\end{tabular}




\section{IGOR GRYGUS, OLHA NAHORNA, STANISLAV TABACHNIKOV, LIUDMYLA PRYMACHOK, OLEKSANDR CHERNIIENKO}

For a comprehensive therapeutic approach, we consider multisystem disorders, focus on the affected systems and potential clinical complications.

The improvement of muscle tone, prevention of orthopedic and respiratory complications, emotional and volitional disorders were predicted as the qualitative result of the physical therapy program.

The results of the implementation of comprehensive physical rehabilitation during 6 months are the establishment of the act of defecation, the absence of respiratory diseases, a norm muscle tony, organized leisure. Anthropometric indicators are consistent with the age of the child: height $-93.3 \mathrm{~cm}$, head circumference -48.2 $\mathrm{cm}$, chest circumference: $52.2 \mathrm{~cm}$, body weight $-16.4 \mathrm{~kg}$.

Laboratory tests have shown that the level of microelements and vitamins has significant changes. Table 2 shows the monitoring of the laboratory tests' results of a child with MSD in the process of physical therapy (Grygus et al., 2019, 2021).

Monitoring the laboratory tests' results of a child with MSD

Table2

\begin{tabular}{|l|c|c|l|l|}
\hline \multirow{3}{*}{ Indicator } & \multicolumn{2}{|c|}{ Result } & \multirow{2}{*}{ Unit } & \multirow{2}{*}{ The reference values } \\
\cline { 2 - 3 } & $\begin{array}{c}\text { At the beginning } \\
\text { of the therapy } \\
(09.2019) \\
\text { Barcode } \\
064094934 \text { (Dila) }\end{array}$ & $\begin{array}{c}\text { After the therapy } \\
\text { (05.2020) Barcode } \\
3601059735 \\
\text { (Synevo) }\end{array}$ & & \\
\hline Serum iron & $8,9^{*}$ & 16.58 & $\mathrm{mcmol} / 1$ & $9-21,5$ \\
\hline $\begin{array}{l}\text { Cyanocobalamin } \\
\text { (vitamin B12) }\end{array}$ & $1471,0 *$ & $966^{*}$ & $\mathrm{pg} / \mathrm{ml}$ & $187-883$ \\
\hline Folic acid & 5,7 & 6.85 & $\mathrm{ng} / \mathrm{ml}$ & $>5,38$ \\
\hline Zinc & $1,033^{*} \mathrm{mg} / \mathrm{l}$ & $117 \mathrm{mcg} / \mathrm{dl}$ & $\begin{array}{l}\mathrm{mg} / \mathrm{l}(\mathrm{Dila}) \\
\mathrm{mcg} / \mathrm{dl} \text { (Synevo) }\end{array}$ & $\begin{array}{l}0,551-0,925 \text { (Dila) } \\
70.0-150.0 \text { (Synevo) }\end{array}$ \\
\hline
\end{tabular}

Note: The symbol * indicates results that go beyond the reference values.

Therefore, according to these blood parameters there is a positive dynamic.

As a result of the conducted study, we may conclude that in domestic and foreign professional publications there is insufficient information on therapeutic management, treatment protocols and clinical guidelines for children with multiple sulfatase deficiency.

It is established that the main problems of this genetic pathology arise due to a combination of neurological lesions, including delay and regression of psychomotor development, and non-neurological cases, such as cardiorespiratory complications and skeletal abnormalities. Isolated treatment attempts are ineffective and temporary.

\section{Discussion}

One of the first reviews of organism systems that are involved in the clinical phenotype of MSD was proposed by Ahrens-Nicklas (2018). This structured set of symptoms and the diagnostic measures give a possibility to confirm or at least suspect or exclude Multiple Sulfatase Deficiency. Ahrens-Nicklas and other (2018) proposed a multi-system approach to the therapeutic review of the main systems of the body. To the recommendations were included: visualization of the spine for signs of instability of the cervical spine and hip joints, scoliosis prophylaxis; control for respiratory system: treatment of respiratory diseases, including obstructive or destructive pulmonary disease, central or obstructive tracheomalacia and apnoea, evaluation of ophthalmic problems, including glaucoma, corneal opacity and retinitis pigment; auditory testing; attention to the potential gastrointestinal problems and the nutrition with the assessment of safe feeding; regular screening of the gallbladder; systematic electrocardiograms and echocardiograms; constant neurological supervision because of peripheral neuropathy, hydrocephalus and cramps; emergency tomography of the brain in a case of acute neurological changes (Ahrens-Nicklas et al., 2018).

Treatment of children with MSD has not been developed yet. Considering that the clinical picture is similar to the late-infantile form of metachromatic leukodystrophy (MIM 250100) (Matalon et al., 2014; Kirilova et al., 2018) or mucopolysaccharidosis (MPS6; MIM 253200) (Burch et al., 1986; Baranov, 2015), it is possible to assume that the treatment of the symptomatic complex can be used in the same way. Thus, cases of allogeneic bone marrow transplantation (or umbilical cord blood) from a healthy donor to patients with metachromatic leukodystrophy have been described in the literature. However, the isolated reports in the professional literature show that attempts to treat with bone marrow or stem cell transplantation only postpone clinical trials for a oneyear period and have no scientific evidence of efficacy (Kirilova et al., 2018; Sun, Berry, 2021).

At the same time, in the literature sources is not indicated whether a comprehension physical rehabilitation program and care strategy, which would focus on preventive care and on improving the quality of children lives with this genetic pathology have been created. 


\section{IGOR GRYGUS, OLHA NAHORNA, STANISLAV TABACHNIKOV, LIUDMYLA PRYMACHOK, OLEKSANDR CHERNIIENKO}

\section{Conclusions.}

The effectiveness of a comprehensive physical therapy program for a patient with multiple sulfatase deficiency has been confirmed, despite the fact, that this genetic pathology is characterized by a malignantly progressive course. In particular, the correct positioning and regular changes of body position allowed to avoid orthopaedic complications.

Regular massage provided norm tony of muscles, cleansing of the skin from dry, ichthyotic plaques, normalization of the defecation act.

Therapeutic physical training contributed to the prevention of hypostatic pneumonia, the preservation of certain functional movements, the restoration of play activity.

Qualitative changes in blood parameters such as serum iron, cyanocobalamin (vitamin B12), folic acid (vitamin B9), zinc were laboratory-confirmed. Anthropometric indicators correspond to the age norm.

The decision of the treatment algorithm and the development of a personalized coordinated comprehensive program of physical therapy of children with MSD require thorough attention.

\section{Compliance with Ethical Standards}

Conflict of Interest The authors declare that they have no conflict of interest.

Ethical Approval All procedures performed in studies involving human participants were in accordance with the ethical standards of the institutional and/or national research committee and with the 1964 Helsinki declaration and its later amendments or comparable ethical standards.

Informed Consent Informed Consent Informed consent was obtained from all individual participants included in the study. All subjects of the institutional survey gave consent for anonymized data to be used for publication purposes.

\section{References}

Ahrens-Nicklas R., Schlotawa L., Ballabio A., Brunetti-Pierri N., De Castro M., Dierks T., Eichler F., Ficicioglu C., Finglas A., Gaertner J. et al. (2018). Complex care of individuals with multiple sulfatase deficiency: Clinical cases and consensus statement. Mol. Genet. Metab. 123:337-346. doi: 10.1016/j.ymgme.2018.01.005

Annunziata I., Bouché V., Lombardi A., Settembre C., Ballabio A. (2007). Multiple sulfatase deficiency is due to hypomorphic mutations of the SUMF1 gene. Hum. Mutat. 28:928. doi: 10.1002/humu.9504

Baranov AA. (2015). Federal clinical recommendations for medical care for children with type mucopolysaccharidosis. Electronic resource. Access mode: http:/www.dkkb-krasnodar.ru/

Burch M., Fensom AH, Jackson M., Pitts-Tucker T., Congdon PJ. (1986). Multiple sulphatase deficiency presenting at birth. Clin. Genet. 30:409-15.doi:10.1111/j.1399-004.1986.tb01899.x. [https://onlinelibrary.wiley.com/doi/abs/10.1002/jimd.12282]

Committee on Healthy Nation, Medical Care and Health Insurance. (2020). Electronic resource. Access mode: http://komzdrav.rada.gov.ua/fsview/74048.html

Dido Y., Dulo O., Gotowski R., Grygus I. (2021). Effect of the goal-oriented physical therapy and ergotherapy tasks and dual task activities on the Berg balance scale and balance indicators in patients with the unilateral neglect. Journal of Physical Education and Sport, 21 (Supplement issue 2). 1234-1241

Grygus I., Nagorna O., Nesterchuk N., Nogas A., Podoliaka P., Gamma T. (2021). A clinical case of physical therapy of a child with multiple sulfatase deficiency. Med. Perspekt. 26(2):202-7. https://doi.org/10.26641/2307-0404.2021.2.234735

Grygus, I., Nagorna, O., Nogas, A., \& Zukow, W. (2019). Anthropological providing educational services to children with special educational needs. Journal of Human Sport and Exercise, 14(4proc), 852-866. doi:https://doi.org/10.14198/jhse.2019.14.Proc4.48

Guerra WF, Verity MA, Philippart M., Fluharty AL, Nguyen HT. (1990). Multiple Sulfatase Deficiency: Clinical, Neuropathological, Ultrastructural and Biochemical Studies. J. Neuropathol. Exp. Neurol., 49:406-423. doi: 10.1097/00005072-199007000-00005.

Horwitz AL. (1979). Genetic complementation studies of multiple sulfatase deficiency. Proc. Natl. Acad. Sci. USA. 76 :6496-6499. doi: 10.1073/pnas.76.12.6496.

Jaszczuk L., Schlotawa L., Dierks T., Ohlenbusch A., Koppenhöfer D., Babicz M., Lejman M., Radhakrishnan K., Ługowska A. (2017). Expanding the genetic cause of multiple sulfatase deficiency: A novel SUMF1 variant in a patient displaying a severe late infantile form of the disease. Mol. Genet. Metab. 121:252258. doi: 10.1016/j.ymgme.2017.05.013

Korolkov A., Kikosh G. (2016). Modern possibilities of orthoses in the complex treatment of equinopolovarus foot deformity in children. Trauma. 17 (4): 96-102. doi: 10.22141/1608- 1706.4.17.2016.77498

Kirilova LG, Miroshnikov OO, Yuzva OO, Radzikhovskaya OV, Gorb AL. (2018). Metachromatic leukodystrophy with schizophrenic onset. Electronic resource. Access mode: https://neuronworld.top/metakhromatichna-leykodistrofiya/ 


\section{IGOR GRYGUS, OLHA NAHORNA, STANISLAV TABACHNIKOV, LIUDMYLA PRYMACHOK, OLEKSANDR CHERNIIENKO}

Lallemant-Dudek P., Durr A. (2021). Clinical and genetic update of hereditary spastic paraparesis. Revue Neurologique. 177(5), 550-556.

Manual Ability Classification System for children with cerebral palsy 4-18 years. (2010). Electronic resourse. Access mode: http://www.macs.nu/downloadcontent.php-

Matalon Michals K., Matalon R. (2014). Encyclopedia of the neurological sciences (second edition). Electronic resource. Access mode: https://www.sciencedirect.com

Multiple sulfatase deficiency. (2021). Electronic resource. Access mode: https://www.malacards.org

Mykhaylova N., Grygus I. (2013). Improving physical performance in children with congenital clubfoot. The journal of orthopaedics trauma surgery and related research. Quarterly. 3 (33). 53-58.

Mykhaylova N., Grygus I., Prusik K., Prusik Ka. (2014). Enhancement of Functional State of Children with Congenital Clubfoot via Physical Rehabilitation. Theory and Practice of Physical Culture. 3: 30-32.

Nesterchuk N, Grygus I, Prusik K, Zukow W. (2019). The technique of physical rehabilitation in clubfoot. Physiotherapy Quarterly, 27(1), 25-34.

Novikov PV. (2014). Lysosomal storage diseases: the topical problem of pediatrics and the current possibilities of pathogenetic treatment. Electronic resource. Access mode: https://www.ped-perinatology.ru

Order of the Ministry of Health of Ukraine N286. (2013). About the statement and introduction of medical and technological documents on standardization of medical care at organic defeats of a brain at children which are followed by motor disturbances. Electronic resource. Access mode: https://zakon.rada.gov.ua/rada/show/v0286282-13\#Text

Phenotypic-genetic relations. (2020). Electronic resource. Access mode: https://www.omim.org/entry/272200

Pichkur NO. (2017). Neuropathic forms of lysosomal diseases accumulation in Ukraine. Electronic resource. Access mode: https://cyberleninka.ru/article/n

Rare diseases. (2020). Electronic resource. Access mode: https://www.slovoidilo.ua/2020/05/28/novyna/suspilstvo/moz-planuyut-stvoryty-naczionalnustratehiyu-shhodo-ridkisnyx-zaxvoryuvan

Savliuk, S., Kashuba, V., Romanova, V., Afanasiev, S., Goncharova, N., Grygus, I., Gotowski, R., Vypasniak, I., Panchuk, A. (2020). Implementation of the Algorithm for Corrective and Preventive Measures in the Process of Adaptive Physical Education of Pupils with Special Needs. Teoriâ Ta Metodika Fizičnogo Vihovannâ, 20(1), 4-11. https://doi.org/10.17309/tmfv.2020.1.01

Savliuk S., Kashuba V., Vypasniak I., Yavorskyy A., Kindrat P., Grygus I., Vakoliuk A., Panchuk I., HagnerDerengowska M. (2020). Differentiated approach for improving the physical condition of children with visual impairment during physical education. Journal of Physical Education and Sport, 20 (Supplement issue 2), 958-965.

Savostyanov RV. (2020). Optimization of molecular diagnostics of rare hereditary diseases in russian patients. Electronic resource. Access mode: https://rsmu.ru

Schlotawa Lars, Laura A. Adang, Karthikeyan Radhakrishnan, and Rebecca C. Ahrens-Nicklas. (2020). Multiple Sulfatase Deficiency: A Disease Comprising Mucopolysaccharidosis, Sphingolipidosis and More Caused by a Defect in Posttranslational Modification [https://www.ncbi.nlm.nih.gov/pmc/articles/PMC7279497/]. doi: 10.3390/ijms21103448

Shestopal N., Balazh N., Kovelska A., Kikh A., Tomanek M., Grygus I. (2021). Effect of rehabilitation program on the quality of life of people with forearm or hand gunshot wounds using physiotherapy methods. Journal of Physical Education and Sport, Vol. 21 (5), 2591-2600.

Sun Angela, Berry Gerard T. (2021). Emery and rimoin's principles and practice of medical genetics and genomics (seventh edition). Electronic resource. Access mode: https://www.sciencedirect.com

Vakulenko D., Vakulenko L, Kutakova O., Pryluts'ka H. (2020). Therapeutic and rehabilitation massage. K. Medicine. 568.

Uttam Garg, Laurie Smith. (2017). Biomarkers in Inborn Errors of Metabolism. 476.

Unified clinical protocol of primary, secondary (specialized) and tertiary (highly specialized) medical care and medical rehabilitation "Cerebral palsy and other organic brain lesions in children with motor disorders. 2019. Electronic resource. Access mode: https://www.dec.gov.ua/wpcontent/uploads/2019/11/2013_286ykpmd_tserparal_dity.pdf

Yevtushenko SK. (2016). Lysosomal diseases of accumulation. Neurology of early childhood. K., 225-2 